\title{
ECONOMIC GROWTH VERSUS ENVIRONMENTAL SUSTAINABILITY: AN ANALYSIS OF ENVIRONMENTAL KUZNETS CURVE IN CASE OF INDIA
}

\author{
Dr. Sumedha Pandey \\ Assistant Professor, Department of Economics, C.M.P. Degree College, Prayagraj, Uttar Pradesh.
}

Article DOI: https://doi.org/10.36713/epra8657

DOI No: $10.36713 /$ epra8657

\begin{abstract}
Economic growth became the buzzword for planners and policymakers after the great devastation of World War II. Every country, rich and poor was planning to achieve higher growth rate to reach the take-off stage (Rostow). In 1950s and early 1960s, economic growth and economic development were considered synonymous but later on, economic development acquired a wider meaning i.e., growth was associated with increase in goods and services while economic development included such important factors like education, health which impact quality of life. But even then, greater emphasis was on economic growth because right from Adam Smith to modern economists, growth was the basic condition of economic welfare. To achieve an ever-increasing growth, resources (natural and man-made) are/were continuously being exploited. But the question that became important here was whether this growth or in wider sense development, sustainable? With time, the form of resource use has changed from usage to exploitation negatively impacting the environment. Can this growth process be allowed at the cost of environmental degradation? So, concerns have been raised from time to time to address this issue. In this context, this paper analyses the impact of rising per capita income, population density and construction activities on carbon emissions (a proxy of environmental degradation) to check the applicability of Environmental Kuznets Curve (EKC) in case of India. Results suggest a positive significant relation between the dependent variable and the independent variables, indicating towards the applicability of EKC in short-run in case of India, but not in the long-run.
\end{abstract}

KEYWORDS: Economic growth, sustainable development, Environmental Kuznets Curve, environmental degradation, carbon emission.

\section{INTRODUCTION}

Mahatma Gandhi said that mother earth has more than sufficient resources to fulfil the needs of everyone (humans and non-humans) but does not have resources to even feed the greed of one human. In fact, this means that human beings are dependent on mother nature which provides them materials for well-being (growth) but it cannot provide unlimited resources for fulfilment of ever-growing demand of development, of growing human population. Humans have been trying to understand the relationship between their demands and environmental capacity. In economics, Malthus was the pioneer of a theory which suggested that population tends to grow faster (exponentially) while food production grows slowly (linearly) so population is automatically checked by nature. The checks come in the form of famines, wars etc. Malthus's effort was only the beginning to understand the relationship between growth of humans and their material needs which are provided by nature. But this relationship of food grains and population growth as depicted by Malthus was only an indicator. High growth of population in 19th century which continues till date resulted in large-scale deforestation due to increasing needs of housing and other activities such as roads, markets, industries and even food. This led to serious research which were undertaken by demographers, geographers, anthropologists, economists and environmental 
scientists to answer some complex questions such as how density of population affects air and water quality or even more difficult questions of climate change and its impact on human productivity, land productivity etc.

\section{LITERATURE REVIEW}

Muthukumara Mani, Anil Markandya, Aarsi Sagar, Sebnem Sahin (2012) in their write up titled 'India's Economic Growth and Environmental Sustainability: What are the Trade-offs?' have discussed the trade-off of economic growth and environmental sustainability. Applying a General Equilibrium Model, the study concludes that reduction in emissions may reduce GDP growth but that reduction is modest and is somewhere offset by the health benefits derived from reduced pollution.

'Economic Growth and Ecological Sustainability in India' by Pranab Mukhopadhyay and Priya Shyamsundar (2012) analyses the relationship between growth and environment in two respect, one related to urbanisation and other related to forest cover. In both cases a relationship is established between the two and the paper concludes making such environmental policies that supports sustainable growth.

Using multiple variables like carbon emissions, economic growth, industrialisation, foreign direct investment and trade openness, Aparna Sajeev and Simrit Kaur (2020) in their article, 'Environmental sustainability, trade and economic growth in India: implications for public policy' have tried to test the relevancy of inverted U-shaped Environmental Kuznets Curve applying autoregressive distributed lag (ARDL) bounds testing approach for cointegration with structural breaks. This article finds existence of U-shaped relationship in the short-run but not in the long-run, thus, concluding formulation of better environment friendly policies.

\section{OBJECTIVE OF THE STUDY}

The present study is being undertaken to analyse the cost-benefit analysis of economic growth of an economy and its impact on the environment in specific context of Environmental Kuznets Curve. Environmental Kuznets Curve maintains that after a particular level of growth, environmental degradation reverses i.e., growth and environment take positive relationship. India has been on the path of economic growth since 1950 and has achieved quite a robust growth in terms of per capita income despite rising population. Now this study is necessary to find whether this robust growth has improved India's environment in respect to air, water and climate.

\section{METHODOLOGY}

The present work is analytical and descriptive in nature. Secondary data sources like World Bank, World Development Indicators, CMIE, Economic Survey have been considered for the purpose of the study. Correlation and regression analysis has been done to check the significance of the relationship between the variables selected for the purpose of evaluating Environmental Kuznets Curve.

\section{HYPOTHESIS OF THE STUDY}

For the purpose of testing the data following hypothesis has been framed:

$\mathbf{H}_{\mathbf{0}}$ : There is no significant relationship between GDP per capita, Population Density and Construction activities on Carbon Emissions in India since 2000.

$\mathbf{H}_{\mathbf{1}}$ : There is a significant relationship between GDP per capita, Population Density and Construction activities on Carbon Emissions in India since 2000.

5.1. Functional relationship to be tested is:

Carbon Emission $=\beta_{0}+\beta_{1}$ GDP Per Capita $+\beta_{2}$ Population Density $+\beta_{3}$ Construction $+\mu_{t}$

\section{RISE IN PER CAPITA GDP, POVERTY REDUCTION AND ENVIRONMENTAL} DEGRADATION

As mentioned above, the growth was the key word for every economy post World War II. It was assumed that growth of output is a solution to all ills, poverty, unemployment, standard of living, peace and harmony, political social unrest and even environment, deforestation and carbon emissions. The much-hypothesized Environmental Kuznets Curve (EKC), suggested that there exists an inverted U-shaped relation between per capita income and environmental degradation indicators $\left(\mathrm{NO}_{2}\right.$ and $\left.\mathrm{SO}_{2}\right)$, deforestation and carbon emission. This sounded like sweet bells of the church to political and policy makers. One may not analyse the statistical or theoretical foundation of EKC but empirically one can see that since 1990, GDP growth has been moderate (very robust in some very populous countries like China, India etc.), the loss to environmental indicators has been quite high. Global forest cover (tree loss) has been on an average 0.437\%(mean) between 1999-2014. 
Urban PM2.5 $\mu \mathrm{g} / \mathrm{m}^{3}$ has increased by an average of $18.924, \mathrm{CO}_{2} \mathrm{~kg} / \$ 0.239$ on an average and $\mathrm{CO}_{2}$ ton p.c. by 3.402 during the same period i.e., all indicators have worsened not even a single indicator has improved. ${ }^{1}$ The study mentioned above covers 95 countries and nearly $85 \%$ population of the globe.

\subsection{Correlation Statistics}

\section{TESTING OF HYPOTHESIS}

\begin{tabular}{|l|c|c|c|c|}
\hline & $\begin{array}{c}\text { Carbon Emissions } \\
\text { (Billion Ton) }\end{array}$ & $\begin{array}{c}\text { GDP Per Capita } \\
\text { in INR }\end{array}$ & $\begin{array}{c}\text { Population } \\
\text { Density in } \\
\text { Square } \\
\text { Kilometre }\end{array}$ & $\begin{array}{c}\text { Constructio } \\
\text { n GVA in } \\
\text { Billion }\end{array}$ \\
\hline Carbon Emissions (Billion Ton) & 1 & 1 & & \\
\hline GDP Per Capita in INR & 0.983035477 & 0.953809894 & 1 & \\
\hline $\begin{array}{l}\text { Population Density in Square } \\
\text { Kilometre }\end{array}$ & 0.984442981 & 0.976022177 & 0.941271942 & 1 \\
\hline Construction GVA in Billion & 0.973803827 & & \\
\hline
\end{tabular}

\subsection{Regression Results}

\begin{tabular}{|c|c|c|c|c|c|c|}
\hline Source & SS & $d f$ & MS & Number of obs & $=$ & 20 \\
\hline Model & 6.20236162 & 3 & 2.06745387 & Prob $>F$ & $=$ & 0.0000 \\
\hline Residual & .047573271 & 16 & .002973329 & $\mathrm{R}$-squared & $=$ & 0.9924 \\
\hline Total & 6.24993489 & 19 & .328943942 & $\begin{array}{l}\text { Ad] } \mathrm{R}_{\text {-squared }} \\
\text { Root MSE }\end{array}$ & $=$ & .05453 \\
\hline
\end{tabular}

\begin{tabular}{r|rrrrrr}
\hline carbonemissionsbillionton & Coef. & Std. Err. & $t$ & P $|t|$ & {$[95 \%$ Conf. Interval] } \\
\hline gdppercapitaininr & $6.93 e-06$ & $2.47 e-06$ & 2.80 & 0.013 & $1.69 e-06$ & .0000122 \\
populationdensityinsquarekilomet & .0096587 & .0014305 & 6.75 & 0.000 & .0066262 & .0126911 \\
constructiongvainbillion & .0000344 & .000018 & 1.92 & 0.073 & $-3.68 \mathrm{e}-06$ & .0000726 \\
cons & -2.413817 & .4572999 & -5.28 & 0.000 & -3.38325 & -1.444385 \\
\hline
\end{tabular}

\footnotetext{
1 'Revisiting the relation between economic growth and environment, a global assessment of deforestation, pollution and carbon emission' Bo Pieter Johannes Andree, Andres Chamorro, Phoebe Spencer, Eric Koomen, Harun Dogo
} 


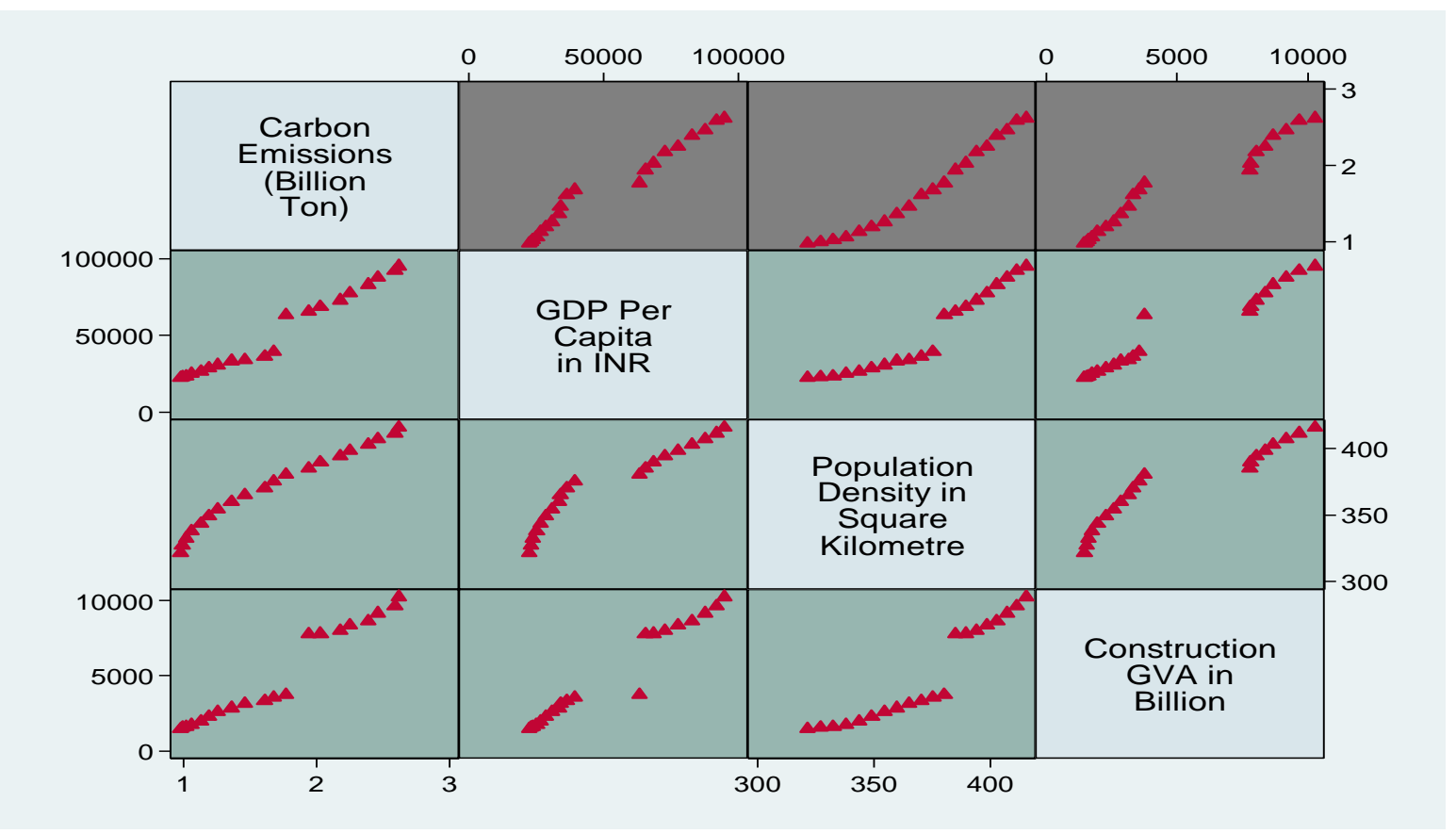

Carbon Emission = -2.41 + 6.93 GDP Per Capita + 0.096 Population Density +0.00003 Construction $+\mu_{\mathrm{t}}$

The regression results suggest a p-value less than 0.05 , with high R-Square value, indicating the rejection of null hypotheses i.e., there is no significant relationship between GDP per capita, Population Density and Construction activities on Carbon Emissions in India since 2000. Also, the grey area in the graph above indicates a positive relationship between Carbon emissions and GDP Per Capita, Population Density, Construction GVA of India.

\section{CARBON EMISSION AND GDP PER CAPITA}

In the context of India, GDP per capita for whole of India has been rising since 1950s. Although the growth was slow in the first 30 years (1950-80) but has been quite robust since then especially so in the first 20 years of the 21 st century. The hypothesis tested by the researcher i.e., there is no evidence of any significant relationship between GDP per capita, population density, construction activities and carbon emissions in India since 2000 $\left(\mathrm{H}_{0}\right)$ is based on the premise of Environmental Kuznets Curve that in the long-run, rise in per capita GDP reduces emissions of hazardous matters with economic growth. In Indian context the researcher has taken 20 years of experience of rise in per capita GDP and carbon emission to find out whether India has reached the top of EKC in 50 years of growth or not. The evidence does not support EKC. $\mathrm{H}_{0}$ is rejected i.e., in India there is still high positive correlation between rise in per capita GDP and carbon emissions so either it does not provide correct theoretical basis of relation between income and pollution level or might be that India has not reached the turning point (the level of income from where EKC shows a declining trend). But as mentioned earlier even in very rich European countries, the turning point is not evident despite various government/non-government efforts. In fact, rise in GDP simply means more goods and services are made available to a stable or a rising population (as in the case of India). More goods and services (houses, transport, roads, malls, schools, hospitals) improve the quality of life although it may not be true always as more production of sin goods can decrease the quality of life of individuals and society. But whatever is produced, quality goods or sin goods, more material, land, woods, would be required especially when the population is rising too fast. It will necessarily create two problems. Firstly, more and more non-renewable resources would be used impacting the future and secondly, a disbalance is created in environment as greater use by human beings means less and less for non-humans. In fact, all sorts of concept of growth and sustainable development has been biased in favour of human beings and therefore, it seems that Malthus was more correct and so are his followers and EKC is not likely to take the shape as suggested. It shall be the effort of all that at least Environmental Kuznets Curve could be straightened after rise if it cannot fall as shown in the following diagram. 
EPRA International Journal of Environmental Economics, Commerce and Educational Management Journal DOI: 10.36713/epra0414 |ISI I.F Value: 0.815|SJIF Impact Factor (2021): 7.743 ISSN: 2348 - 814X Volume: 8 | Issue: 10 | October 2021
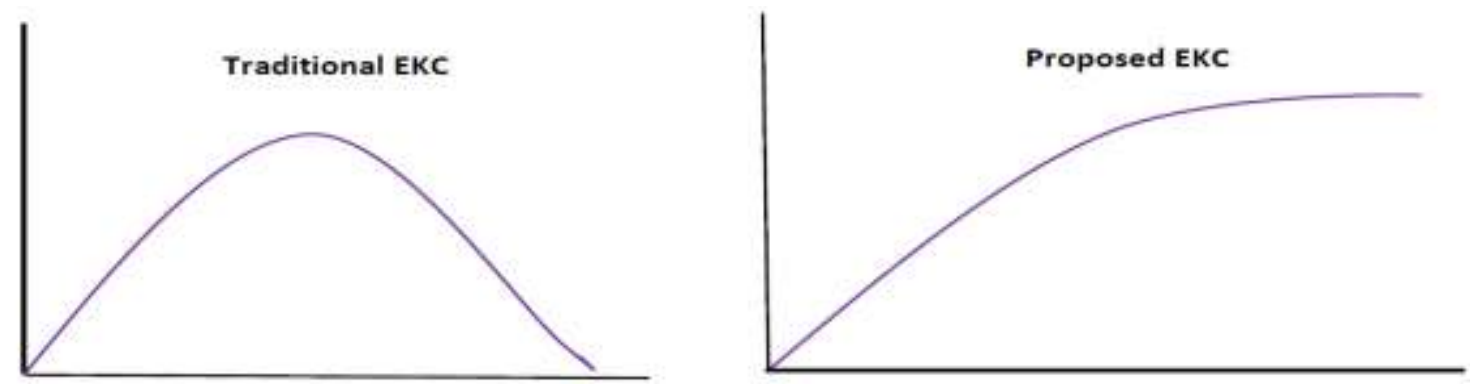

Figure 1: Carbon Emission and GDP Per Capita of India

\section{CARBON EMISSION AND GDP PER CAPITA OF INDIA}

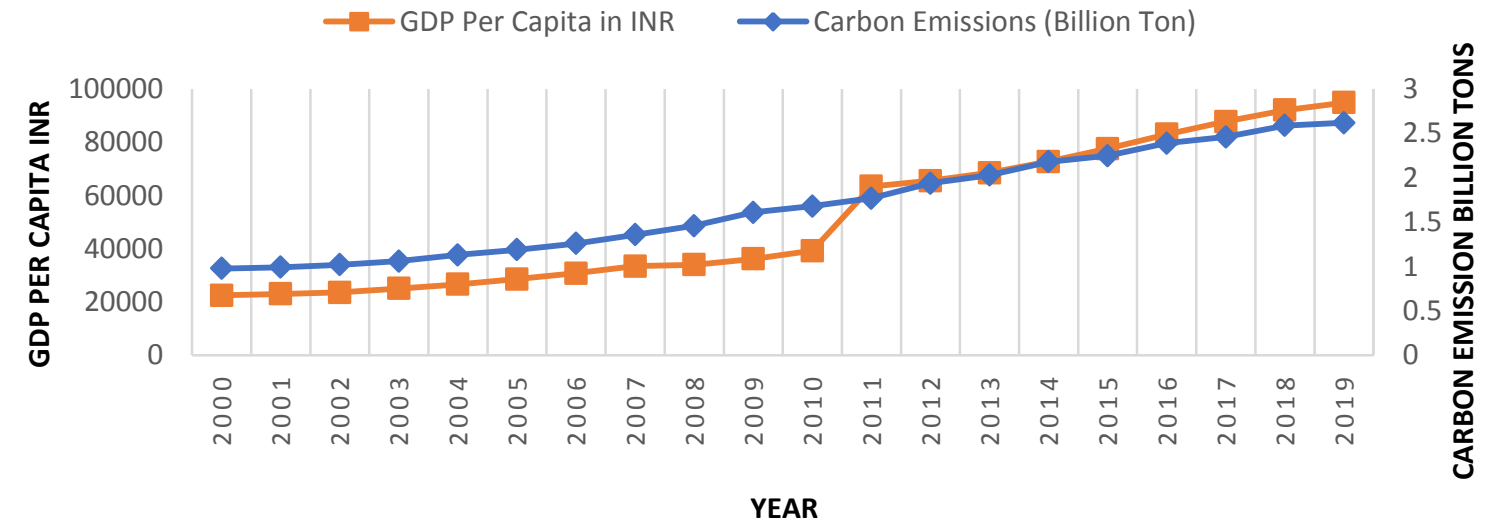

Source: Computed

Table I: Carbon Emissions, GDP Per Capita, Population Density and Construction GVA of India

\begin{tabular}{|c|c|c|c|c|}
\hline Year & $\begin{array}{c}\text { Carbon Emissions } \\
\text { (Billion Ton) }\end{array}$ & $\begin{array}{c}\text { GDP Per Capita } \\
\text { in INR }\end{array}$ & $\begin{array}{c}\text { Population Density in } \\
\text { Square Kilometre }\end{array}$ & $\begin{array}{c}\text { Construction GVA in } \\
\text { Billion }\end{array}$ \\
\hline $\mathbf{2 0 0 0}$ & 0.97843 & 22491 & 321.42 & 1463.8 \\
\hline $\mathbf{2 0 0 1}$ & 0.99253 & 23095 & 327.02 & 1553.78 \\
\hline $\mathbf{2 0 0 2}$ & 1.02 & 23607 & 332.59 & 1615.74 \\
\hline $\mathbf{2 0 0 3}$ & 1.06 & 25116 & 338.13 & 1749.59 \\
\hline $\mathbf{2 0 0 4}$ & 1.13 & 26629 & 343.64 & 2288.55 \\
\hline $\mathbf{2 0 0 5}$ & 1.19 & 28639 & 349.11 & 2581.29 \\
\hline $\mathbf{2 0 0 6}$ & 1.26 & 30805 & 354.55 & 2848.06 \\
\hline $\mathbf{2 0 0 7}$ & 1.36 & 33446 & 359.94 & 3154.95 \\
\hline $\mathbf{2 0 0 8}$ & 1.46 & 33987 & 365.25 & 3323.29 \\
\hline $\mathbf{2 0 0 9}$ & 1.61 & 36249 & 370.44 & 3544.36 \\
\hline $\mathbf{2 0 1 0}$ & 1.68 & 39270 & 375.47 & 7773.35 \\
\hline $\mathbf{2 0 1 1}$ & 1.77 & 63462 & 380.34 & 7800.5 \\
\hline $\mathbf{2 0 1 2}$ & 1.94 & 65538 & 385.06 & 8007.71 \\
\hline $\mathbf{2 0 1 3}$ & 2.03 & 68572 & 389.64 & 8352.29 \\
\hline $\mathbf{2 0 1 4}$ & 2.18 & 72805 & 394.13 & 8653.35 \\
\hline $\mathbf{2 0 1 5}$ & 2.25 & 77659 & 398.55 & 9164.45 \\
\hline $\mathbf{2 0 1 6}$ & 2.39 & 83003 & 402.92 & 9643.06 \\
\hline $\mathbf{2 0 1 7}$ & 2.46 & 87828 & 407.23 & 10254.46 \\
\hline $\mathbf{2 0 1 8}$ & 2.59 & 92085 & 411.48 & 415.67 \\
\hline $\mathbf{2 0 1 9}$ & 2.62 & 94954 & & \\
\hline $\mathbf{2 0 u r}$ & & & & \\
\hline
\end{tabular}

Source: World Bank. World Development Indicators, Economic Survey

If one glances over the table and accompanying graph, it becomes quite evident that in India since 2000 up to 2019, GDP per capita, population density and construction activities are rising which are supposedly good news 
for Indian policymakers. But one can also find that carbon emission and air pollution and water pollution is also rising which does not augur well for the future. Carbon emissions have more than doubled during this period while air pollution (air quality index) is very high in almost all cities and has reached to the dangerous limits especially in New Delhi, Bangalore, Chennai, Mumbai and Kolkata. Smaller towns and rural areas are also now facing the problem of climate change. Based on the above table, one can easily conclude that there is a significant positive relationship between population density, construction expenditure, rising per capita income and carbon emissions. India is a developing country and certainly it wants that its citizens enjoy a high standard of living but now one must rethink the strategy of development. Present strategy of high rate of growth especially in manufacturing may pay dividends as service and manufacturing have no impact on environment but even in these areas choice should be sector and product specific. Programmes like Make in India with zero effect even if they have some defect is advisable. SME are most suited to Indian economy. Construction sector is time specific i.e., beyond a point it would not be required to create infrastructure but population needs to be checked at all levels. Since 2011, population growth has slowed down and demographers feel that by 2042 India will attain replacement levels but by then Indian population will reach around 170 million. The government and community must now rethink to control it below 150 million at all cost. Similarly, afforestation and maintaining eco hotspots must be the greatest priority along with distribution of population and choice of crop as per agroclimatic zone.

\section{POPULATION AND SUSTAINABLE DEVELOPMENT - A MYTH}

One must remember that population growth was very high in last four decades of $20^{\text {th }}$ century all around the globe as well as in India. The population of the world doubled in 40 years from around 3 billion to 6 billion, while in India, it reached a staggering 1 billion from around 60 million. If one looks at demographic variables only, it may sound wonderful, life expectancy has increased, infant mortality has gone down, most deadly diseases have been overcome, deaths in famines is all-time low all over the world and India as well, but if one looks at its impact on the environment it sounds like a death knell. Most mineral resources are now vanishing, air and water pollution has worsened, carbon emissions have grown enormously, the Earth's temperature is rising, cyclones and typhoons have become a regular phenomenon (in India at least 8 cyclones have hit between 2000-2020), forest area is now lowest in 200 years. In states like Uttar Pradesh, forest area is only $2 \%$ of surface area against recommended area of $22 \%$. All this is happening not only because the population is rising but also because the demands of individuals with respect to needs of life are rising at a faster pace. On one hand, the increase in population leads to greater demand of food and nourishment leading to greater demand of agriculture farming, horticulture, sericulture, animal husbandry. On the other side the demand of housing, schools, hospitals, factories, offices are also rising. Both of these result in deforestation and reduced availability of fallow land and even deserts. Moreover, the composition of population and urbanisation leads to greater requirement of transport, power etc. which again affects the natural and mineral resources. Another problem is distribution of population among different locations. There are various areas of Africa, South Asia and Latin America where fertility is very high while in developed countries of Europe and North America as well as Australia, it is quite low. This creates multiple problems. The poor nations with high fertility are very poor and this poverty forces them to use natural resources beyond replacement level in most cases. Forest, fisheries are some such examples. This also leads to higher level of migration from high fertility area to low fertility area and both of above phenomenon create a problem of unorganised unplanned urbanisation. This urbanisation leads to construction of unnecessary infrastructure like flyovers, roads, malls etc. The construction and transport are two most important causes of pollution. But one has to remember that increased demand of food in agriculture has also led to increased demand of chemicals, insecticides, pesticides leading to greater salinity and arid soil which also results in water pollution, loss of aqua products. The increasing smoke from transportation and particulate matter (PM10) causes health hazards affecting lung capacity and overall productivity of human beings. In the present research paper, the researcher has analysed the impact of population growth (taking density of population as proxy variable) and per capita income (proxy for demand of goods and services) to study their impact on environment. 
Figure 2: Carbon Emission and Population Density in India CARBON EMISSION AND POPULATION DENSITY IN INDIA

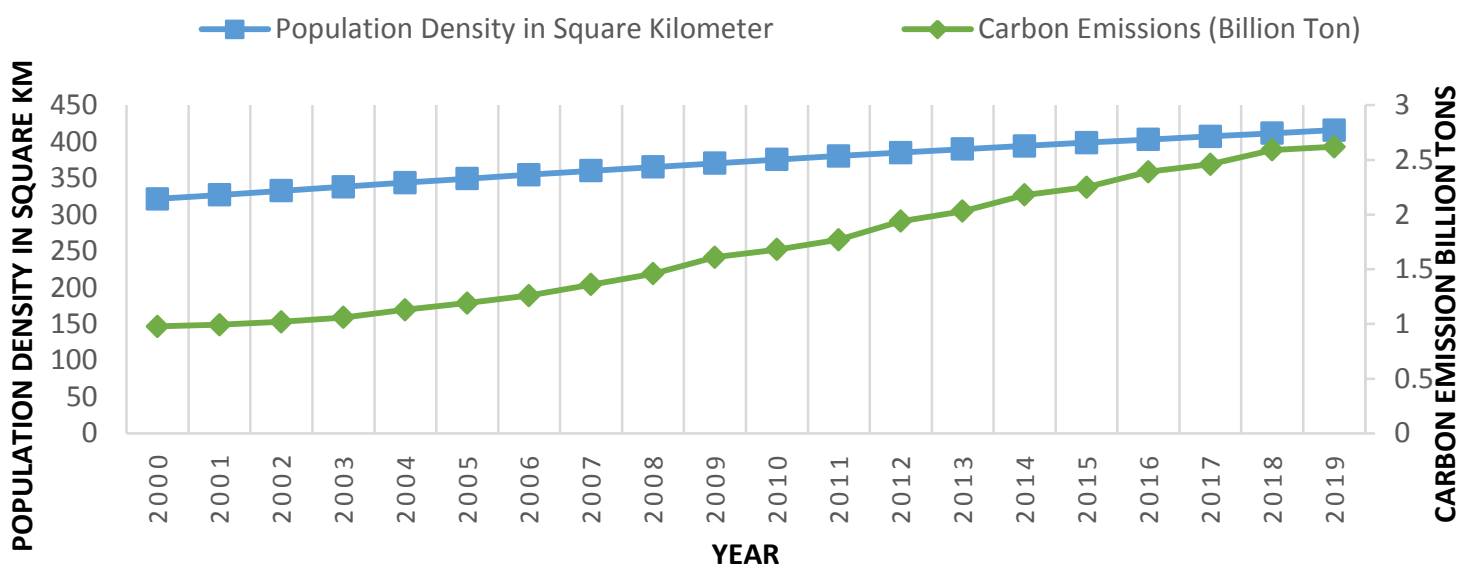

\section{Source: Computed}

The second variable of the regression equation taken by the researcher in context of India can be called an extension of EKC. Environmental Kuznets Curve shows the relationship between rising incomes and pollution levels. But higher income tends to increase population (law of subsistence wages). In fact, growth of income and technology also leads to population growth. One can see in India that with rise in incomes and technology, life expectancy has increased from around 54 years (in 1950) to around 66 years (in 2020). Similarly, infant mortality rate has gone down, malnourishment has been reduced. So, population density rises. The researcher has taken rise in population density as an indicator of quality of life (enhancement of health, education and infrastructure) and its impact on pollution (carbon emission). As the multiple regression result fails to accept the null hypothesis, it means there exists a significant relationship between population density and carbon emission as well, meaning to say that although improved technology and standards have helped human beings grow but at the cost of environment. This is again true for the whole world but can be proved with the evidence of India. In last 20 years, the density in whole of India has increased from around 340 per square kilometre to 450 per square kilometre naturally due to increase in population because land surface is fixed. If population density rises, then needs (qualitative and quantitative) would rise. Scientists have developed chemical fertilisers, pesticides and insecticides to increase horticulture, grains, vegetables and pulses but this has created great problem of water and air pollution as well as destruction of various flora and fauna. Despite great efforts by scientists more than 5 million varieties of animal and plant kingdom have become extinct and few are at the verge of extinction. The Environmental Kuznets Curve demonstrates that greener technologies, less polluting technologies will emerge but here again, till date not much evidences have been found in Indian context.

\section{ENVIRONMENTAL POLLUTION AND CONSTRUCTION}

The third variable has specifically been taken up in this research paper to find out as to how much construction activity impacts the environmental standards because in India one finds almost all million plus cities have air standards which remain between highly unsatisfactory to hazardous.

In India, since ancient times houses were constructed by mud, tree stems, tree leaves and other waste materials found in nature. These houses decayed after 5 to 6 years and new ones were constructed but there was no loss to habitat or nature. Similar stories could be found everywhere. Houses were built in hills by tree logs, stones in deserts and so on. In medieval -ages, building became more magnificent. Palaces and havelis of royalty can be seen everywhere but even then, loss to nature was minimal. Today, construction industry is one of the biggest industries all over the world. In case of India, nearly 10\% of GDP is now invested in construction activity and is probably the second largest industry in terms of employment. The government, every day announces budget for new highways to be constructed. Road, rail infrastructure growth is supposed to be the key to economic growth. But one should not forget that construction is one activity which probably if not necessarily the largest contributor to environmental degradation. According to new researches, construction sector contributes more than $20 \%$ to air pollution, more than $50 \%$ cause of climate change, $40 \%$ of drinking water pollution, $40 \%$ of worldwide energy use (causing damage through various means) and $50 \%$ of landfill wastes. This data of BIMhow Blog may look exaggerated of facts but it is certain if one goes through various metros and their 
satellites one finds significant changes in the surface of land (due to removing the trees and other plants) which is necessitated for construction. All building materials used now i.e., cement, concrete, aluminium, steel, plywood, sand are not natural products. Their production leads to high level of carbon emission. In construction, today various chemicals are used which harm the human workers. Moreover, the amount of dust, mud and noise of construction sites pollute air and water. Moreover, construction of flyovers and multi-storeyed buildings do have adverse impact on biodiversity of a place leading to loss of very important flora and fauna. Every developed country is now looking for options of green building (less loss to environment) but in poorer countries construction is the biggest source of employment and environmental concerns are not even an issue. The politicians and even the courts have somehow agreed to allow growth to gain prime hand over environmental concerns. Sardar Sarovar, Tehri Dam and many such cases are clear examples.

Figure 3: Carbon Emission and Construction GVA in India

\section{CARBON EMISSION AND CONSTRUCTION GVA IN INDIA}

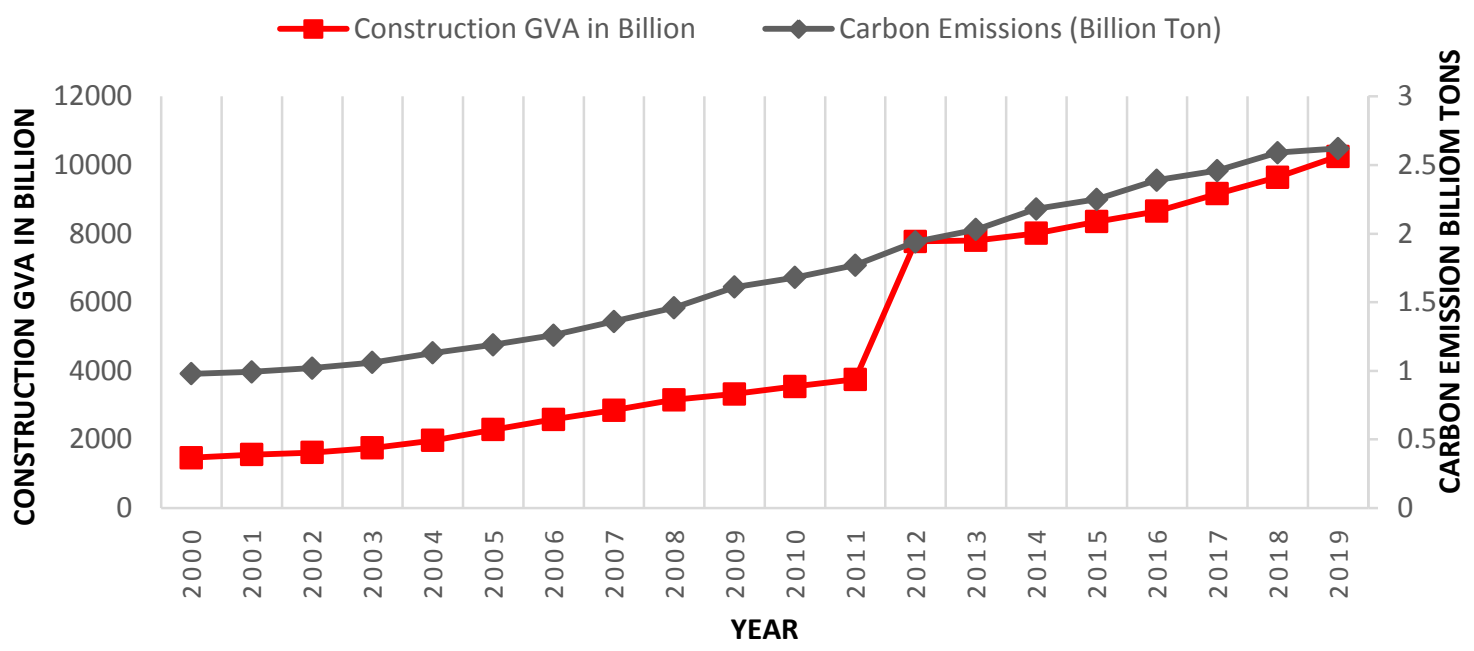

Source: Computed

As mentioned above, null hypothesis was rejected which is also clear in Table I. In Indian context, the scientists need to create new kinds of building materials appropriate to geographical locations just as in Japan where volcanoes regularly hit. Similarly, some things need to be done specifically like more mountains and sea coast housing. This variable suggests that one of the greatest dangers in India of pollution is from construction activities which may endanger human existence.

\section{CONCLUSION}

Once a teacher asked a question in a research class 'why we have brakes in all cars, motorcycles and even in cycles? Many students answered differently. For example, for safety, for precaution but the teacher was not satisfied. His answer was 'for speed'. He explained that you can only speed up your vehicle if you have brakes otherwise you will be very cautious and can never attain speed. The same thing relates to sustainability. You cannot attain high growth if you do not have brakes (sustainability). Speed alone could lead your economy to crashes. If you know that you have the brakes with you then higher growth is achievable. This was the mistake that planners and policymakers did in second half of the 20th century and at present the globe is facing dangers of various kinds like climate change, environmental degradation, air pollution, extinction of species and what not. Scientists and environmentalists have been speaking of these dangers for many years now. In India, many social activists like Sundar Bahuguna, Medha Patkar, Vandana shiva had been fighting for the cause of sustainable development. But the problem is that of 'tragedy of commons'. Everyone believes that his contribution to environmental degradation is very small and hence he should be allowed to benefit himself but the combined contribution becomes huge. Another problem is that it is not time reversible. We cannot reverse what has been done in past therefore, one needs to clearly estimate the causes which impact more on environment positively or negatively and then move ahead. Population growth, growth of transport, growth of construction activities, growth of non-degradable material has negative impact on sustainability while afforestation, green bordering, green technologies, reusable and recyclable products help growth along with 
sustainable development. As in a vehicle accelerator and brakes both are required to reach your destination similarly, limits to growth need to be accepted for sustainable development.

\section{REFERENCES}

1. Bhagwati, J., 1993. The case for free trade. Scientific American. pp: $42-49$.

2. Chambers, R.G., R. Färe and S. Grosskopf, 1996. Productivity growth in APEC countries. Pacific. Economic Review, 1(1): 181-190.

3. Grossman, G.M. and A.B. Krueger, 1995. Economic growth and the environment. Quarterly Journal of Economics, 110(2): $353-377$.

4. Mani Muthukumara, Markandya Anil, Sagar Aarsi, Sahin Sebnem (2012), India's Economic Growth and Environmental Sustainability: What are the trade offs?, Green Policy Platform.

5. Mukhopadhyay Pranab and Shyamsundar Priya (2012), Economic Growth and Ecological Sustainability in India, Economics and Finance, Economic Development, Econometrics, Experimental and Quantitative Methods Online Publication Date: Nov 2012DOI: 10.1093/oxfordhb/9780199734580.013.0020.

6. Sajeev Aparna, Kaur Simrit (2020), Environmental sustainability, trade and economic growth in India: implications for public policy, International Trade, Politics and Development ,ISSN: 2586-3932, emerald.com

7. Shafik, N., \& Bandyopadhyay, S.(1992). Economic growth and environmental quality: Time series and crosscountry evidence, background paper for the world development report. Washington, DC: The World Bank, 1992. 